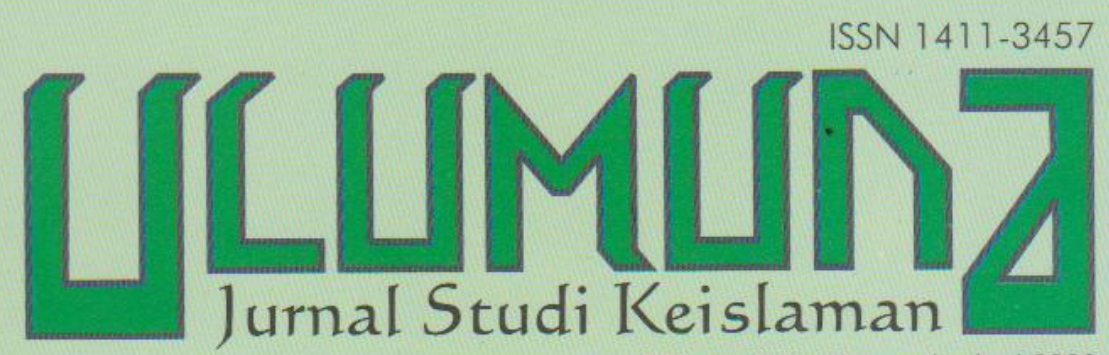

Volume XIII• Nomor $1 \cdot$ Juni 2009

TERAKREDITASI Berdasarkan SK Dirjen Dikti Depdiknas Nomor: 65a/DIKTV/Kep/2008

PEMIKIRAN FIQH DAN SPIRIT TRANSFORMASI SOSIAL Miftahul Huda

PERSPEKTIF MUHAMMAD SAT́D AL-ASYMÂWI TENTANG HISTORISITAS SYARI'AH Mutawalli

ASAS RETROAKTIF PADA KASUS PELANGgARAN HAM (PERSPEKTIF HUKUM ISLAM) Ikhwan

BMT DAN DEMOKRATISASI EKONOM: MEMBUMIKAN EKONOMI SYARIAH DI INDONESIA Lukman A - H Lkim

DINAMIKA PEMIKIRAN FIQH DALAM NU: ANALISIS ATAS NALAR FIQH POLA MAZHAB Ahmad Arifi

KOMPROMI DAN INTERSEKSIONALITAS GENDER DALAM PEMBERIAN MAHAR: TRADISI AMPA COI NDAI PADA SUKU MBOJO Atun Wardatun 


\section{PEDOMAN TRANSLITERASI}

\begin{tabular}{|c|c|c|c|}
\hline Arab & Latin & Arab & Latin \\
\hline 1 & $=$ & = & $=\mathrm{f}$ \\
\hline ب & $=$ & ق & $=\mathrm{q}$ \\
\hline$\dot{H}$ & ts & ك & $=\mathrm{k}$ \\
\hline 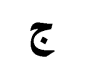 & $=$ & $J=$ & $=1$ \\
\hline$\tau$ & $=$ & b & $=\mathrm{m}$ \\
\hline$\dot{\tau}$ & $=\quad \mathbf{k h}$ & ن & $=\mathbf{n}$ \\
\hline$د$ & $=$ & و & $=\mathbf{w}$ \\
\hline$\dot{j}$ & $\mathrm{dz}$ & $\Delta$ & $=\mathbf{h}$ \\
\hline J & $=$ & $\varepsilon$ & $=$, \\
\hline j & $=$ & 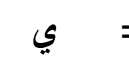 & $=\mathbf{y}$ \\
\hline س & $=$ & & \\
\hline ش ش & $\begin{array}{l}=\quad \text { sy } \\
=\quad \text { sh }\end{array}$ & \multicolumn{2}{|c|}{$\begin{array}{l}\text { Untuk Madd } \\
\text { dan Diftong }\end{array}$} \\
\hline ض & dl & $i$ & $=\hat{a}$ (a panjang) \\
\hline b & th & = & $=\hat{\mathbf{i}}(\mathbf{i}$ panjang $)$ \\
\hline ظ & $\mathbf{z h}$ & أو = & $=\hat{\mathbf{u}}$ (u panjang) \\
\hline$\varepsilon$ & $=$ & آو = & $=\mathbf{a w}$ \\
\hline$\dot{\varepsilon}$ & $=\mathbf{g h}$ & = آين & $=$ ay \\
\hline
\end{tabular}


TransLiterasi

ARTIKEL

Miftahul Huda

Mutawalli

Ikhwan

Kasjim Salenda

Hamid Fahmy

Rusli

Ahmad Arifi

Atun Wardatun
Pemikiran Fiqh

dan Spirit Transformasi Sosial $\bullet$ 1-22

Perspektif Muhammad Sa'îd al-Asymâwî

tentang Historisitas Syari'ah • 23-58

Asas Retroaktif

pada Kasus Pelanggaran HAM

(Perspektif Hukum Islam) • 59-80

Terorisme

dalam Perspektif Hukum Islam • 81-108

Genealogi

Liberalisasi Pemikiran Islam • 109-140

Kontroversi Akhbârî-Ushûlî

dalam Tradisi Pemikiran

Syı̀'ah Imâmiyyah • 141-168

Lukman Al-Hakim

BMT dan Demokratisasi Ekonomi:

Membumikan Ekonomi Syari'ah

di Indonesia • 169-188

Dinamika Pemikiran Fiqh dalam NU:

Analisis atas Nalar Fiqh

Pola Mazhab • 189-216.

Kompromi dan Interseksionalitas Gender dalam Pemberian Mahar: Tradisi Ampa

Co’i Ndai pada Suku Mbojo • 217-236.

\section{INDEKS}




\title{
PEMIKIRAN FIQH \\ DAN SPIRIT TRANSFORMASI SOSIAL
}

\author{
Miftahul Huda*
}

\section{Abstract}

In the context of social dynamics and world ideologies contestation that bring social implications, efforts to reconstruct and to revitalize the sharia's concepts are always be needed. The efforts are aimed at making the sharia remain to be relevant to the needs of. modern societies and to take significant roles in transformation of both individual life and social order.

Generally, such a 'project' consist of very efforts of reorientation of fiqh visions, reactualizing its methodology, focusing its substance, strengthening the existing social institutions, and developing various new social institutions that are needed as field of small experimentation that will be improved and applied in wider scales in the future. Through the 'project' it is hoped that the Islamic law should be simpler but more comprehensive and argumentative. The sharia "face" that up till now seems to be static, conservative, and pro status quo will change to be more alive, innovative, and future-vissioned.

Keywords: Fiqh, Visi Sosio-Moral, Transformasi, Reorientasi, Rekonstruksi, Revitalisasi.

MENGAITKAN konsep hukum Islam (fiqh) dengan visi transformasi sosial dapat dibawa ke dua arah pembahasan: pertama, di satu sisi, konsep hukum Islam hendaknya memiliki peran yang signifikan bagi upaya melakukan transformasi sosial demi terciptanya kehidupan yang lebih mencerminkan nilai-nilai fundamental syari'ah seperti keadilan, kesalehan, dan keluhuran martabat manusia. Kedua demi tercapainya tujuan-tujuan idealnya itu, interpretasi atas sumber-sumber ajaran syari'ah menjadi

*Penulis adalah dosen pada Fakultas Syari'ah IAIN Mataram, Jln. Pendidikan 35 Mataram. email: miftahuda09@gmail.com. 
konsep-konsep hukum (fiqh) ${ }^{1}$ dan langkah aplikasinya harus disesuaikan dengan kebutuhan, dan kesiapan sosiologis masyarakat dengan tetap konsisten pada tujuan dan visi asasinya.

Fakta bahwa Islam bukan hanya agama ritual, tetapi merupakan risälah agung bagi gerakan transformasi sosial antara lain terlihat dari aksentuasinya pada shalat dan zakat. Di banyak ayat al-Qur'an, shalat tidak disebut tanpa diiringi dengan zakat. ${ }^{2}$ Zakat dimaksudkan untuk mendistribusikan secara sistemik sebagian dari harta orang-orang yang kaya kepada fakir miskin, membebaskan budak, membantu mereka yang terhimpit hutang, dan memberikan kemudahan bagi ibn sabîl. ${ }^{3}$

Di negeri Arab waktu itu, langkah tersebut dirasakan sebagai hal baru yang sangat revolusioner. Karena itu, kalangan bisnis Mekkah yang merasa kepentingannya terancam segera melakukan perlawanan terhadap Nabi. ${ }^{4}$ Mereka sebenarnya tidak menolak sepenuhnya ajaran keagamaan Nabi (khususnya tentang doktrin dan ritual penyembahan satu Tuhan atau tawhîd) karena hal itu tidak terlalu merisaukan mereka. ${ }^{5}$ Sesungguhnya yang

${ }^{1}$ Secara literal kata syariah berarti jalan menuju tempat air. Dalam terminologi kajian Islam, kata tersebut berarti jalan lempang atau kehidupan yang benar menuju Tuhan; atau jalan yang diperintahkan oleh Tuhan agar setiap mukmin mengikutinya. Pada abad ke-9 H/ 13 M, ketika formulasi teologi Islam dikristalkan untuk pertama kalinya dan kata syari'ah mulai digunakan dalam pengertian yang sistematis, maknanya dibatasi pemakaiannya untuk menyebut hukum saja (yang kemudan disebut Fiqh) sedang teologi dikeluarkan dari cakupan maknanya. Lihat Muhammad Saied al-Asymawi, "Fiqh Islam" dalam Islam Negara dan Hukum, ed. Heijer dkk. (Jakarta: INIS, 1993), 119-31. Abd al-Wahhâb Khallâf mendefinisikan fiqh sebagai bukum-bukum syariah yang bersifat amaliyah yang diperoleh dari dalildalil yang rinci. Abd al-Wahhâb Khallâf, 'Ilm Ushûl al-Fiqh (Jakarta: Majlis alA'lâ al-Indunisi li al-Da'wah al-Islâmiyyah, 1972), 11. Dari sini penulis memahami fiqh (dengan semua variannya) sebagai versi-versi pemahaman terhadap syari'ah Islam pada sisi hukumnya.

${ }^{2}$ Lebih dari 20 ayat yang memuat perintah shalat dan dirangkai dengan zakat misalnya dalam surat al-Baqarah (2): 43, 83, 110, 177, 277; al-Nisâ (4): 77; al-Taubah (9): 5 dan sebagainya.

${ }^{3}$ Qs. al-Taubah (9): 60.

${ }^{4}$ Asghar Ali Engineer, Islam dan Pembebasan, ter. Hairus Salim HS \& Imam Baehaqi (Yogyakarta: LKiS, 1993), 6.

${ }^{5}$ Qs. al-Ankabût (29): 61, 63; Luqmân (31): 25; al-Zumar (39): 38; alFath (43): 87. 
paling mereka khawatirkan adalah implikasi sosial-ekonomi dari risâlah tersebut. ${ }^{6}$

Nabi Muhammad adalah seorang revolusioner baik dalam kata maupun perbuatannya. Ia bekerja untuk mendorong perubahan (transformasi) struktur masyarakatnya. Ia mendobrak suasana mapan (yang penuh ketimpangan sosial) di kota Mekkah yang dikuasai oleh penguasa politik dan orang-orang kaya di kota itu. ${ }^{7}$ Dengan demikian, sekalipun mula-mula Islam bangkit sebagai gerakan keagamaan, lebih dari itu ia sesungguhnya juga membawa pesan transformatif dengan visi sosial yang jauh dan mendalam. ${ }^{8}$ Nilai-nilai transformatif dari risâlah itu tetap relevan bagi kehidupan umat manusia hingga kini.

Dalam bidang politik, misalnya, al-Qur'an dengan tegas menekankan pentingnya penciptaan masyarakat yang egaliter dan berkeadilan. Berulang kali al-Qur'an mengingatkan bahwa masyarakat beriman harus senantiasa bersikap adil, ${ }^{9}$ termasuk dalam urusan yang menyangkut kepentingan diri sendiri dan kaum kerabat. ${ }^{10}$ Keadilan harus ditegakkan bagi siapa pun dengan mengabaikan perasaan suka atau tidak suka. ${ }^{11}$ Juga ditegaskan bahwa setiap orang hendaknya bekerja dan mendapatkan posisi sesuai dengan kapasitas dan keahliannya. ${ }^{12}$ Contoh-contoh tersebut hanyalah sebagian dari pesan-pesan sosio-politik dalam al-Qur'an dan diperjuangkan sepanjang hayat oleh Rasulullah Muhammad Saw.

Dalam lapangan perekonomian, sekalipun ditegaskan bahwa setiap orang berhak memperoleh imbalan sepadan atas pekerjaannya, ${ }^{13}$ secara kolektif masyarakat harus berupaya membangun sistem perekonomian yang dapat mencegah akumulasi kekayaan secara berlebihan pada kelompok tertentu. ${ }^{14}$

\footnotetext{
${ }^{6}$ Engineer, Islam..., 5.

${ }^{7}$ Ibid., 7 .

${ }^{8}$ Ibid., 5.

I'Ibid., 23.

${ }^{10}$ Qs. al-Nisâ (4): 135.

${ }^{11}$ Qs. al-Mâ'idah (5): 42.

${ }^{12}$ Qs. al-Isrâ' (17): 84.

${ }^{13}$ Qs. al-Nisâ (4): 32.

${ }^{14}$ Qs. al- $\underline{H}$ asyr (59): 7.
} 
Hal itu akan menciptakan kesenjangan yang mencolok sehingga akan menimbulkan gejolak sosial yang menghancurkan modal sosial (social capital) yang ada dalam masyarakat.

Dalam kehidupan sosial secara umum, al-Qur'an menganggap semua manusia setara tanpa melihat perbedaan kesempurnaan fisik, warna kulit, jender, ras atau kebangsaan, sehingga secara prinsip setiap individu berhak mendapatkan perlakuan yang sama dalam semua lapangan kehidupan berdasarkan prinsip keadilan dan penghargaan atas keluhuran martabatnya sebagai manusia. Oleh karena itu, institusi sosial apa pun yang hendak dibangun harus mengacu pada prinsip-prinsip moral yang fundamental tersebut.

Islam mengajarkan bahwa kemuliaan manusia terletak pada kesalehannya dalam menjalani hidup (taqwâa). ${ }^{15}$ Yang dimaksudkan di sini tidak hanya kesalehan religius dengan kesungguhan menjalankan ritual agama secara cermat, tetapi juga kesalehan sosial karena al-Qur'an menyejajarkan kesalehan dengan keadilan. ${ }^{16}$ Nilai-nilai moral utama dalam kehidupan secara umum seperti kejujuran ${ }^{17}$, empati18, ketabahan, ${ }^{19}$ dan optimis dalam menjalani hidup ${ }^{20}$ serta keteguhan untuk menjalani hidup di jalan kebenaran, ${ }^{21}$ mendapatkan porsi perhatian yang besar.

Pentingnya pengembangan konsep-konsep hukum Islam (fiqh) yang memiliki spirit transformasi sosial, baik dalam teori maupun penerapannya, antara lain dilatari beberapa alasan.

Pertama, masih kuatnya kecenderungan spiritualisasi hukum syari'ah, yakni suatu pandangan bahwa kepatuhan terhadap aturan syari'ah semata-mata merupakan persoalan religius, tidak berkaitan dengan tujuan meningkatkan kesejahteraan dan membangun peradaban di dunia. Pemikiran hukum mengenai kehidupan sosial yang disusun hanya atas dasar argumen rujukan

${ }^{15}$ Qs. al- Hujurât (49): 13.

${ }^{16}$ Qs. al-Mâ’idah (5): 8; lihat juga Engineer, Islam... , 24.

${ }^{17}$ Qs. al-Ghâsyiyah (83): 1-4.

${ }^{18}$ Qs. al-Mâ'ûn (107): 1-3.

${ }^{19}$ Qs. al-Baqarah (2): 155, 156

${ }^{20}$ Qs. al-Kahf (13): 87.

${ }^{21}$ Qs. al-Rûm (30): 41. 
teks literal menunjukkan bahwa yang menjadi perhatian terpenting adalah mematuhi makna literal teks itu. Hal ini tampak, misalnya, pada contoh-contoh argumen kewajiban menuntut ilmu, ${ }^{22}$ haramnya praktek suap-menyuap ${ }^{23}$, larangan membuat gambar fotografi ${ }^{24}$ serta aturan-aturan lain dalam bidang ekonomi, ${ }^{25}$ politik ${ }^{26}$ dan bidang kemasyarakatan lainnya ${ }^{27}$ yang sepenuhnya disandarkan pada rujukan makna literal teks syari'ah.

Seperti dijelaskan Hassan Hanafi, pemikiran keagaman umat Islam pada umumnya bertumpu pada model "upaya pengalihan teks ke dalam realitas seakan-akan teks keagamaan adalah realitas yang dapat "berbicara" sendiri. Menurutnya, metode tekstual semacam itu mengandung banyak kelemahan yang amat mendasar. $^{28} \mathrm{Hal}$ ini pula yang dirisaukan oleh Najm al-Din al-

${ }^{22}$ Banyak teks hadis yang dijadikan argumen, misalnya sebuah hadis yang diriwayatkan Ibn 'Abd al-Barr dari sahabat 'Anas bin Mâlik Rasulullah pernah bersabda, "Menuntut ilmu itu fardlu bagi setiap muslim. Dan sesungguhnya penunut ilmu dimintakan ampun kepada Allah (istighfâr) oleh segala sesuatu hingga ikan-ikan yang hidup di laut." Sayyid Ahmad al-

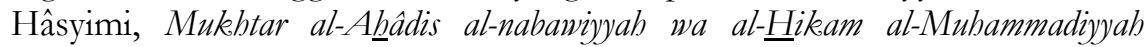
(Semarang: Toha Putra, tt), 93. Pengertian menuntut ilmu (Thalab al-Tlm) yang dimaksud di sini pada umumnya dibatasi pada ilmu-ilmu yang terkait dengan syari'ah dan bukan ilmu-ilmu yang dianggap "duniawi" sekalipun memberikan manfaat bagi kehidupan umat manusia seperti Matematika, Elektronika, Ekologi, dan Kimia. Kewajibannya pun dipahami bersifat individual.

${ }^{23}$ Argumen teks mengenai suap-menyuap antara lain hadis yang diwayatkan al-Thabrânî, "Orang yang menyuap dan yang menerima suap (sama-sama) akan masuk ke dalam neraka. Ibid., 82.

${ }^{24}$ Muhammad Nashiruddin al-Albani, Fatwa-fatwa Syaikh Nashiruddin alAlbani, ter. Taqdir Muhammad Arsyad (Yogyakarta: Media Hidayah, 2004), 148.

${ }^{25}$ Misalnya larangan mengambil manfaat dan memperdagangkan alkohol (untuk tujuan apa pun), Ibid., 144.

${ }^{26}$ Misalnya larangan bergabung dalam parlemen. Ibid. , 117.

${ }^{27}$ Misalnya larangan tinggal di negeri nonmuslim (kafir). Ibid., 133.

${ }^{28}$ Kazuo Shimogaki, Kiri Islam Antara Modernisme dan Post-modernisme Telaah Kritis atas Pemikiran Hassan Hanafi (Yogyakarta: LKiS, 1993), 119-21. Dalam edisi ini terjemahan karya asli Hassan Hanafi dilampirkan lengkap pada bagian belakang. 
Thufi (1276-1316 M) dan mengantarkan kepada gagasannya tentang mashlabah yang khas. ${ }^{29}$

Pandangan keagamaan yang hanya berorentasi pada spiritualitas akan cenderung dogmatis dalam memandang berbagai aspek kehidupan dan mereduksi ajaran agama sebatas kegiatan ritual dan aktivitas sosial yang bersifat karitatif, serta mengarah pada pandangan yang pesimistik terhadap kehidupan dunia. Pola pemikiran seperti itu akan semakin menjauhkan nilai-nilai syari'ah Islam dari kehidupan masyarakat dan melemahkan spirit umat untuk membangun peradaban di berbagai sisi kehidupan. ${ }^{30}$

Kedua, apa yang dikatakan sebagai "kemajuan" dalam kehidupan sosial ternyata selalu menampakkan wajah ambiguitasnya. Dalam bidang ekonomi misalnya, "kemajuan" memang membuat sebagian warga masyarakat bisa menikmati kesejahteraan, tanpa harus terlalu bersusah payah, bahkan melebihi apa yang sesungguhnya mereka perlukan menurut standar orang banyak. Namun, bagi sebagian besar lainnya, "kemajuan" itu justru membuat nilai pekerjaan dan kesejahteraan mereka menurun secara drastis hingga mereka terperangkap kian jauh dalam kemiskinan dan ketidakberdayaan sekalipun sudah bekerja keras sepanjang waktu.

Keterpurukan nasib mereka itu tidak sepenuhnya disebabkan oleh kesalahan mereka sendiri, melainkan juga karena bekerjanya sistem sosial yang tidak adil dan cenderung menindas yang lemah. Akibatnya, manfaat dari setiap kemajuan justru lebih banyak dinikmati oleh mereka yang sudah makmur, sementara

${ }^{29}$ Abdallah M. al-Husayn al-'Amiri, Dekonstruksi Sumber Hukum Islam, Pemikiran Hukum Najm ad-Din Thufi, ter. Abdul Basyir (Jakarta: Gaya Media Pratama, 2004), 42-5. Pada edisi ini terjemahan teks asli karya al-Thufi dilampirkan pada bagian belakang.

${ }^{30}$ Fenomena seperti ini, misalnya, tampak pada komunitas-komunitas penganut mazhab yang berpegang secara ketat pada pola pemahaman teks syari'ah secara literal. Pola pemahaman seperti itu cenderung membatasi visi duniawi guna membangun peradaban sehingga dalam urusan yang dianggap duniawi mereka kurang menaruh perhatian, serta kurang mampu melakukan kritik konstruktif untuk memperbaiki sistem yang ada, baik pada sistem ekonomi, politik, ilmu pengetahuan, dan lain-lain. Dalam masalah-masalah tersebut pada umumnya mereka bersikap pasif atau reaktif. 
warga yang lemah justru terperosok semakin jauh dalam ketidakberdayaan.

Dalam masyarakat modern yang kompleks, situasi seperti itu tidak bisa ditangani hanya dengan mengandalkan pendekatan personal, misalnya lewat fatwa $\hat{a}$ wajib zakat atau himbauan berinfâq bagi mereka yang kaya dan ajakan untuk bekerja lebih keras bagi si miskin. Dalam hal ini yang harus ditata ulang adalah sistem sosial dan sistem perekonomiannya agar tercipta tatanan baru yang lebih memungkinkan kaum dlu'afâ bangkit membebaskan diri dari keterpurukan, sedangkan mereka yang kaya juga tetap dapat mengembangkan usahanya.

Ketiga, tanpa visi transformasi yang jelas, setiap kasus atau pertanyaan mengenai hukum cenderung ditanggapi (dijawab) satu demi satu dengan diktum, dalil, dan logikanya sendirisendiri terpisah satu sama lain, bahkan terkadang kontradiktif satu sama lain. Sesungguhnya tidak semua pertanyaan layak diangkat sebagai tema diskursus hukum karena banyak kasus yang sesungguhnya sangat kondisional.

Misalnya, pertanyaan tentang seberapa lama seorang perempuan menjalani masa haid dan berapa lama waktu suci di antara dua haidnya. Mengenai masalah ini para ulama punya pendapat yang berbeda-beda dengan argumennya masingmasing. ${ }^{31}$ Namun, sebenarnya masalah ini tidak perlu diangkat dalam sebuah diskursus hukum apalagi hanya didasarkan pada argumen-argumen teks syari'ah. Hal itu karena lama waktu haid merupakan masalah fisiologis-alamiah yang amat dipengaruhi

${ }^{31}$ Ibn Rusyd, Bidâyah al-Mujtahid wa Nihâyah al-Muqtashid, Juz I (Ttp.: Dâr Ihyâ al-Kutub al-'Arabiyyah, tt.), 36. Shabîh al-Bukhari dan Shabîh Muslim dua referensi yang menjadi rujukan utama para ulama dalam hal hadis hukum menurunkan bab khusus tentang haidl, tetapi tidak menyinggung sedikit pun tentang masalah ukuran waktu haid ini Dalam salah satu hadis yang dikutip di dalamnya Rasulullah pernah bersabda kepada um al-mu'minin 'Aisyah ra: "... Jika haid mulai datang kepadamu, berhentilah shalat dan jika telah lewat "masanya" (fa idza dzahaba qadraha), maka basuhlah/mandilah dan mulai shalatlah kamu...." Lihat Abû 'Abd al-Lâh Muhammad bin Ismâ'îl al-Bukhârî, Matn al- Bukhârî (Jeddah-Singapura-Indonesia: alHaramain, tt.), 63-5. Lihat pula Muslim bin Hajjaj al-Qusyairy al-Naisabury, Shậîh Muslim, juz II (Dâr Ihyâ al-Kutub al-Arabiyyah Indunisiyyah, tt.), 2989 dan juz I, 136. 
oleh usia, asupan gizi, pola makan, kondisi fisik, suasana psikis, gaya hidup, dan hal-hal lain yang sifatnya individual sehingga tidak bisa dibuat aturan hukum yang digeneralisasi.

Dalam hal ini, dari sisi figh, sebenarnya yang lebih penting adalah membahas apa yang boleh dan tidak boleh dilakukan oleh perempuan yang sedang haid, sementara soal hitungan waktu haid biarkan masing-masing perempuan menyikapinya berdasarkan pengalamannya sendiri-sendiri.

\section{Karakteristik}

Pemikiran tentang fiqh transformatif bukanlah sebuah tawaran "mazhab" yang sama sekali baru di samping mazhab-mazhab fiqh yang sudah ada, melainkan lebih merupakan "rangkuman" unsur-unsur positif, dan revitalisasi pemikiran figh yang sudah ada, termasuk khazanah pemikiran hukum (tsarwah fiqhiyyah) terdahulu, yang di samping memiliki argumen ( dari sumber al-nushûsh al syar'iyyah juga dipertajam lagi pada aspek visi, isi, metodologi, maupun strategi implementasinya dalam kehidupan umat. ${ }^{32}$

\section{Penegasan Visi}

Pada aspek visi, fiqh (sebagai varian tafsir atas ajaran syari'ah) seharusnya tidak hanya melegitimasi dan menjustifikasi apa yang sudah berlaku, melainkan secara progresif harus diarahkan untuk mendorong terjadinya perubahan dan perbaikan di masa depan, baik pada aspek-aspek yang sifatnya fisik lahiriah maupun batiniah.

Visi ini bertolak dari asumsi mendasar bahwa upaya mewujudkan cita-cita sosio-moral al-Qur'an dan syari'ah Islam merupakan agenda perjuangan yang tak pernah berhenti

32Perspektif komprehensif yang meliputi visi, isi, metode, dan strategi implementasi merupakan salah satu bagian terpenting yang ditawarkan dalam tulisan ini. Sejumlah ulama dan cendekiawan memang telah melakukan apa yang diusulkan di sini, tetapi konsep-konsep fiqh pada umumnya tidak memiliki atau hanya memiliki sebagian dari unsur-unsur itu. Misalnya banyak karya figh dengan muatan materi dan bidang kehidupan yang sangat luas hingga berjilid-jilid, tetapi secara substansial tidak memperlihatkan visi transformatif yang komprehensif pada sisi-sisi lainnya. 
sepanjang waktu karena tidak ada satu pun komunitas masyarakat yang benar-benar telah sempurna dalam semua seginya hingga tidak lagi memerlukan perbaikan.

Fiqh transformatif (dan para ulamanya) tidak membatasi perhatiannya hanya pada "diskusi-diskusi" teoretik untuk menetapkan kompilasi legal judgement atau keputusan hukum

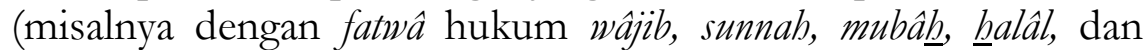
harâm) ${ }^{33}$ melainkan secara konsisten berorentasi pada prinsip progresivitas untuk mendorong terciptanya suasana kehidupan yang semakin baik dari waktu ke waktu. ${ }^{34}$

\section{Penajaman Fokus Isi}

Dalam aspek materiilnya, konsep figh seharusnya memenuhi sejumlah parameter sebagai berikut.

Pertama, pengembangan konsep hukum harus menggunakan cara pandang yang komprehensif atas kehidupan manusia baik bidang ritual, ekonomi, politik, maupun bidang kehidupan sosial lainnya yang saling berkait. Pengembangan konsep Fiqh tidak boleh hanya memperhatikan bidang-bidang tertentu misalnya ibadah ritual, melainkan juga mencakup bidang-bidang lainnya yang terus berkembang. Hal itu karena setiap aspek kehidupan memiliki kaitan yang erat dengan aspek-aspek lainnya, sehingga konsep hukum di setiap aspek harus dikembangkan dalam konteks kaitannya dengan aspek-aspek lainnya.

Misalnya ritual haji bukanlah perintah yang berdiri sendiri, tetapi juga terkait dengan dimensi kehidupan yang luas baik dalam kehidupan individual maupun kolektif. Oleh karena itu, perintah haji, betapa pun pentingnya dan besarnya janji pahala di akhirat, tidak boleh dilakukan dengan mengabaikan perintah lainnya seperti tanggung jawab memberi nafkah terhadap

${ }^{33}$ Karya-karya mengenai fiqh pada umumnya, kalau tidak bisa dikatakan semuanya, membatasi perhatiannya pada penetapan legal judgement ini, yakni penjelasan tentang status hukum perbuatan tertentu (wâjib, sunnah, harâm dan lain-lain) dan prosedur pelaksanaannya, baik disertai penjelasan tentang dalildalilnya atau tidak.

${ }^{34}$ Mengenai prinsip ini, bandingkan dengan Fazlur Rahman, "Hukum dan Etika dalam Islam”, dalam Jurnal Al-Hikmah, No. 9 (Bandung: Yayasan Muttahari, 1993), 39. 
keluarga, pendidikan anak, memberikan ASI bagi balita, dan solidaritas sosial terhadap kerabat yang tergolong dlu'afâ. Sisi figh yang penting dikaji di sini adalah konsep kriteria mampu (istithâ'ah) seperti yang diungkapkan al-Qur'an. ${ }^{35}$ Komprehensivitas cara pandang tersebut semakin urgen pada pengembangan konsep-konsep hukum yang secara jelas menyentuh masalah kebijakan dan kepentingan publik yang luas.

Kedua, adanya perspektif integratif antara target-target yang bersifat formal dengan visi sosio-moral yang lebih substansial. Hal itu karena syari'ah Islam memiliki dua aspek yang tidak boleh dipisahkan, yakni aspek formalitas (figh) yang menjelaskan aturan / prosedur yang sifatnya lahiriah, dan aspek yang terkait dengan tujuan sosio-moral. Konsep al-Ghazali yang menggabungkan bab-bab pembahasan fiqh dengan spirit tasawuf dalam I I yya' 'Ulûm al-Din merupakan contoh yang menarik.

Muhammad Abû Zahrah merumuskan tujuan umum syari'ah Islam dalam tiga tema besar, yaitu mensucikan jiwa (tahdẑ̧̨́b alnafs) demi membentuk individu-individu berkarakter saleh, menegakkan keadilan sosial (iqâmah al-'adl fî al-mujtama) serta membangun dan meningkatkan taraf kesejahteraan hidup (tab $q \hat{\imath} q$ al-mashlabah) bagi semua warga masyarakat. ${ }^{36}$ Pertimbangan yang sungguh-sungguh atas tujuan sosio-moral ini amat penting agar konsep fiqh benar-benar dijiwai semangat tersebut.

Misalnya secara formal (fiqh) pernikahan diatur dengan ketentuan syarth, rukn dan prosedur formal tertentu. Namun dalam mengamalkan perintah nikah seharusnya tidak berhenti pada aspek formalitas karena aspek formalitas saja tidak akan dapat mewujudkan pernikahan dan kehidupan keluarga yang

${ }^{35}$ Qs. Âli Imrân (3): 97. Para ulama fiqh membatasi kriteria istithâah pada sisi kemampuan fisik, harta kekayaan (perbekalan) dan keamanan selama di perjalanan dan selama menunaikan ibadah haji. Di antara mereka ada yang tetap mewajibkan ibadah haji bagi mereka yang belum memiliki perbekalan, tetapi bisa mencari bekal di perjalanan (misalnya dengan bekerja atau bahkan dengan minta-minta). Mereka tidak mencantumkan syarat ketersediaan nafkah/biaya hidup bagi keluarga yang ditinggalkan apalagi keperluan lainnya seperti biaya kesehatan, pedidikan, ketersediaan susu/ASI untuk balita dan sebagainya. Lihat Ibn Rusyd, Bidâyah..., 233.

${ }^{36}$ Muhammad Abû Zahrah, Ushûl al-Fiqh (Bairut: Dâr al-Fikr, tt.), 76. 
indah dan bahagia, melainkan harus berorentasi lebih jauh pada nilai-nilai pernikahan, yaitu membangun keluarga yang sejahtera, terpenuhinya hak-hak masing-masing pihak, serta untuk membangun generasi umat yang lebih berkualitas di masa depan.

Berbagai hasil ijtihad para ulama terdahulu yang secara substansial kurang mencerminkan tujuan luhur pernikahan perlu dikaji ulang secara kritis, seperti konsep tentang hak memaksakan pernikahan (jjbâr) orang tua terhadap putrinya, pernikahan di bawah umur, prosedur perceraian yang terlalu mudah (hanya dengan ucapan anti thâliq), tradisi mahar yang mahal, konsep kufu' berdasarkan ras dan silsilah kebangsawanan, dan sebagainya. Dalam penyusunan aturan hukum formal oleh lembaga-lembaga yang memiliki fungsi legislasi, pertimbangan atas tujuan sosio-moral tersebut harus mendapatkan perhatian yang sungguh-sungguh.

Khusus konsep fiqh yang terkait dengan kegiatan ritual memang tidak perlu dilakukan perubahan dalam skala besar pada aspek teknis-formalnya karena hal itu akan terasa mengurangi nilai otentitasnya. ${ }^{37}$ Namun, kegiatan ritual tidak boleh terhenti pada pelaksanaan aturan-aturan formal lahiriah (fiqh) yang secermat-cermatnya, melainkan juga harus beranjak lebih jauh dengan upaya menghayati dan mewujudkan tujuan-tujuan sosiomoralnya. Misalnya dalam mengamalkan ritual shalat seharusnya tidak hanya berhenti pada kecermatan pelaksanaan rukun dan kefasihan pengucapan bacaan al-Qur'an dan doa yang ada di dalamnya (aspek fiqh) ${ }^{38}$ tetapi juga pada usaha melakukannya dengan khusyû,39 dan merealisasikan tujuan shalat untuk membangun karakter invdividu saleh ${ }^{40}$ serta membangun kehidupan kolektif yang lebih damai, egaliter, dan berkeadilan.

37Persoalan otentisitas ini telah memicu perdebatan yang sengit terkait dengan konsep pemikiran tentang sunnah dan bid'ah. Namun, karena belum dibuat konsep parameter dan distingsi yang jelas, lengkap, dan sistematis dari semua pihak yang berdebat tersebut, pada akhirnya masing-masing melihatnya dengan perspektif sendiri-sendiri.

${ }^{38}$ Misalnya tampak pada karya Syekh Nashiruddin al-Albani, Sifat Shalat Nabi Saw., ter. Muhammad Thalib (Yogyakarta: Media Hidayah, 2000).

${ }^{39}$ Qs. al-Mu'minûn (23): 1.

${ }^{40}$ Qs. al-'Ankabût (29): 45. 
Ketiga, pengembangan konsep fiqh harus mengintegrasikan orientasi wawasan kehidupan akhirat dan duniawi sekaligus. Hal itu karena sekalipun orientasi utama setiap muslim adalah mencari ridla Allah swt. dan kebahagiaan akhirat, tetapi juga tidak boleh melupakan pentingnya membangun kehidupan dunia. ${ }^{41}$ Apalagi untuk menggapai kebahagiaan akhirat mereka juga memerlukan sarana yang sifatnya duniawi. Dengan kehidupan yang sejahtera, seorang beriman lebih banyak berkesempatan untuk memperbanyak amal akhirat dan amal sosial, misalnya zakat, sedekah, haji, serta menjauhkan mereka dari perbuatan dosa seperti korupsi, mencuri, dan mencari penghasilan di sektor ekonomi yang haram.

Dengan standar kesejahteraan yang tinggi, bahkan mereka tidak hanya membantu kaum dlu'afâ, tetapi juga melakukan aksi kepedulian terhadap binatang dan lingkungan hidup untuk menyelamatkan bumi dan segenap umat manusia. Karena dalam ajaran Islam kepedulian terhadap nasib binatang yang tengah menderita pun dapat menjadi bagian dari kesalehan religius yang membawa pahala di akhirat. ${ }^{42}$

Dalam hal ini kiranya apresiasi patut diberikan kepada para ulama dan cendekiawan yang mengembangkan kajian-kajian Islam yang baru, seperti lingkungan hidup, pengobatan, ekonomi kerakyatan, dan perbankan dari perspektif ajaran Islam. Tidak

${ }^{41}$ Qs. al-Qashash (38): 77.

42Sebuah hadis yang diriwayatkan Abû Hurairah dan dimuat dalam Shabih Muslim mengungkapkan kisah yang diceritakan Rasulullah saw. bahwa dahulu pernah ada seorang laki-laki yang kehausan (karena kehabisan bekal air minum) di perjalanan. Ketika menemukan sebuah sumur dia segera turun ke dalamnya dan segera melepaskan rasa dahaga yang tak tertahankan. Saat naik dari dalam sumur tiba-tiba datang menghampirinya seekor anjing yang tampak sangat kehausan dan menjilat-jilat pasir. Dalam hatinya dia berkata, "aduh kasihan anjing ini kehausan seperti saya tadi". Dia pun segera turun lagi ke dalam sumur untuk mengambil air. Sambil menggigit sepatunya yang penuh air dia merangkak naik lalu memberi minum anjing tersebut hingga puas. Dia bersyukur bisa melakukan itu dan dia pun mendapat ampunan dari Allah swt." Para sahabat pun bertanya kepada Rasul: "Ya Rasul, apakah kita akan mendapat pahala dengan berbuat baik kepada binatang ?" Rasul pun menjawab, "Pada (amal kebajikan terhadap) setiap makhluk hidup terdapat pahala." Muslim bin Hajjaj al-Qusyairy al-Naisabury, Shabih Muslim..., juz II, 298-9. 
tertutup kemungkinan kajian-kajian tersebut akan melahirkan cabang-cabang fiqh baru yang prospektif dan terus berkembang di masa depan.

Keempat, pengembangan konsep hukum Islam harus dilakukan dengan mengintegrasikan aspek kehidupan individual dan kolektif. Maksudnya spirit yang menjiwai hukum Islam seharusnya tidak terbatas pada upaya transformasi psiko-moral individual membentuk pribadi-pribadi yang religius, saleh, dan patuh kepada aturan agama, melainkan juga upaya untuk membangun sistem politik, ekonomi, dan sistem sosial lainnya yang lebih mencerminkan nilai-nilai luhur syari'ah seperti keadilan, kesederajatan, hak asasi, dan empati terhadap nasib sesama.

Langkah pengembangan fiqh "struktural" tersebut dimaksudkan agar implementasi nilai-nilai syari'ah tidak sematamata bergantung pada kemauan individual, melainkan berkembang secara sistemik karena tidak semua individu memiliki loyalitas yang tinggi terhadap ajaran syari'ah. Misalnya dalam menangani masalah korupsi dan suap-menyuap (rasywah) terhadap pejabat negara, langkah yang dilakukan tidak cukup dengan fatwa harâm dan ancaman hukuman masuk neraka bagi koruptor berikut dalil-dalil syari'ah (al-Qur'an, hadis, dan lainlain), melainkan juga dibarengi dengan upaya membangun konsep fiqh politik (fiqh al-Siyâsah) yang visioner dan berorentasi pada pengembangan sistem atas dasar prinsip good governance.

Untuk keperluan tersebut, huijah (argumen hukum) yang diperlukan tidak cukup hanya menggunakan dalil-dalil yang berasal dari teks-teks syari'ah dan analisis istinbath seperti yang sudah ada, melainkan juga argumen empirik mengenai praktek suap-menyuap, varian modus operandi-nya serta implikasi buruknya bagi kehidupan umat, disertai paparan fakta, hasil riset, dan data yang akurat. Oleh karena, itu keterlibatan para pakar dan para spesialis di berbagai bidang amat diperlukan untuk mengkaji tema-tema hukum yang hendak dikembangkan.

\section{Strategi Implementasi}

Langkah penerapan hukum Islam (fiqh) harus dilakukan dengan memperhatikan beberapa hal berikut ini. 
Pertama, penerapan hukum syari'ah harus mengikuti tahapan kesiapan sosiologis dan momentum situasi. Artinya, konsep fiqh harus terus dikembangkan secara dinamis sesuai dengan prinsip tasyrî' dan tahapan perkembangan sosiologis di setiap lingkungan masyarakat. Dalam hal ini ada tiga prinsip tasyrî' yang penting diperhatikan, yaitu prinsip pentahapan gradual (al-tadrîj), prinsip meminimalkan jumlah aturan formal (taqlîl al-taqnîn) dan prinsip tidak mempersulit kehidupan umat ('adam al-haraj). ${ }^{43}$

Memang pengamalan ajaran syari'ah seharusnya tidak hanya terhenti dalam batas paling minimal seperti dalam ketentuan fiqh. ${ }^{44}$ Namun untuk mewujudkan tujuan ideal tersebut tidak dapat dilakukan secara drastis dan serentak misalnya lewat aturan formal dan kekuatan politik, melainkan harus melalui proses pentahapan yang terencana mulai dari langkah sosialisasi untuk meyakinkan publik tentang kebenaran, dan manfaatnya bagi kehidupan mereka, hingga antisipasi atas resistensi sosial dan akibat-akibat negatif yang mungkin timbul.

Situasi khusus juga perlu dipertimbangkan dengan seksama. Misalnya, ketika masyarakat sedang dalam kesulitan ekonomi seharusnya (sementara) tidak diterapkan aturan-aturan ekonomi yang justru bisa lebih menyengsarakan umat, sekalipun kebijakan itu memiliki argumen teks-teks syari'ah yang meyakinkan. ${ }^{45}$

Dalam kasus dan situasi tertentu perlu juga dipertimbangkan untuk tidak langsung diberikan keputusan hukum (legal judgement) yang pasti seperti keputusan hukum wâjib, sunnah, dan barâm,

${ }^{43}$ Muhammad al-Khudlarî Bik, Târîkh al-Tasyrî’ al-Islâmî (Dâr Ihyâ alKutub al-'Arabiyyah, 1981) 17-20.

${ }^{44}$ Misalnya, sekalipun dalam fiqh disebutkan bahwa pada jenis harta tertentu porsi kewajiban zakat adalah sebesar 2,5 persen, bagi mereka yang diberi karunia harta kekayaan melimpah seharusnya tidak membatasi dana sosialnya hanya dalam hitungan 2,5 persen, melainkan terus meningkatkan porsinya dari waktu ke waktu sebagai ekspresi rasa syukur dan kepatuhan kepada Allah swt. Contoh teladan mengenai hal itu telah diberikan oleh Rasulullah, para sahabat beliau, dan banyak tokoh umat sejak generasi awal.

${ }^{45}$ Contoh mengenai hal ini antara lain pada kebijakan Khalifah Umar bin Khattab dalam masalah ghanimah dan penangguhan hukuman bagi pencuri. Lihat Amiur Nuruddin, Ijtihad Umar bin Khaththab Studi tentang Perubahan dalam Hukum Islam (Jakarta: Rajawali Press, 1991), 137-66. Mengenai kebijakan khas Khalifah Umar yang lain lihat juga Munawir Syadzali, Ijtihad Kemanusiaan (Jakarta: Paramadina, 1997), 37-43. 
tetapi direspons dalam bentuk nasihat, himbauan moral atau mainstreaming suatu pandangan atau visi tertentu berikut argumen sosialnya. Pendekatan ini sebenarnya juga dicontohkan dalam alQur'an, misalnya dalam kasus pelarangan khamr. ${ }^{46}$

Penjelasan di atas menggarisbawahi pendapat bahwa perubahan aturan hukum pada aspek teknis bukan hanya diperbolehkan, tetapi justru harus dilakukan. Hal itu dimaksudkan agar penerapan aturan hukum dapat mendorong tercapainya cita-cita sosio-moral syari'ah dalam suasana yang aman dan damai. ${ }^{47}$

Kedua, penerapan aturan hukum perlu menggunakan berbagai instrumen kekuatan sosial yang memungkinkan, baik politik, ekonomi, maupun kultur. Hal ini karena setiap aturan hukum memiliki karakteristiknya sendiri-sendiri sehingga tidak mungkin dipaksakan semuanya, misalnya melalui pendekatan legal dengan menjadikannya sebagai undang-undang negara. Ada aturan yang lebih cocok diterapkan melalui pendekatan politik hukum (legal policy) dan ada yang lebih cocok lewat pendidikan, atau pedekatan lainnya. Institusi sosial yang baik juga berfungsi dalam menyatukan visi dan penyelesaiaan perbedaan pendapat di antara para ulama dan cendekiawan.

Dalam konteks ini penting pula membangun kultur hukum yang baik melalui pendekatan sosial dan kultural. Karena dengan kultur hukum yang baik sebenarnya tidak diperlukan aturan formal dalam jumlah besar karena, tanpa aturan formal pun, para warga masyarakat telah memiliki kesadaran moral yang tinggi untuk menjaga dirinya dari perbuatan maksiat dan yang merugikan warga masyarakat yang lain.

Ketiga, implementasi hukum syari'ah, juga perlu memperhatikan pentingnya memanfaatkan dan mewujudkan institusi sosial yang baik dan efektif. Hal itu karena jika berpegang secara ekstrem kepada prinsip otonomi individu

${ }^{46}$ Qs. al-Baqarah (2): 219; al-Nisâ (4): 43, dan al-Mâidah (5): 90.

${ }^{47}$ Bandingkan dengan konsep Naẓhariyât al-Mîâan al-Sya'rânî. Lihat Miftahul Huda, "Keragaman Fiqh dan Spirit Pembebasan Kajian atas Pemikiran al-Sya'rani (1492-1565) tentang Ikhtilâf dalam al-Mî́ân al-Kubrâ" dalam Jurnal Istinbath, Vol. 4, No. 2 (Juni 2007), 137-62. 
dalam segala hal, akan banyak hak individu dan kepentingan publik yang tidak terlindungi.

Misalnya dalam persoalan minuman keras (khamr) dan narkotika, para ulama seharusnya tidak hanya mengajak warga masyarakat untuk tidak melakukan perbuatan terkutuk itu melalui sosialisasi fatwa haramnya khamr, tetapi juga harus mendesak para pemegang kendali pemerintahan untuk menerapkan kebijakan "no drug" secara konsisten sekalipun langkah itu mungkin membawa kerugian pada aspek tertentu seperti PHK karyawan pabrik minuman keras, berkurangnya sebagian sumber devisa dan menurunnya jumlah wisatawan mancanegara. Kebijakan seperti itu harus dilakukan demi menjaga kemaslahatan umat yang lebih luas.

Implementasi aturan syari'ah juga harus dirancang secara terpadu dan sistematis mulai dari hulu hingga ke hilir. Langkah itu meliputi upaya penciptaan suasana sosial yang kondusif, sosialisasi, penanganan kasus, hingga penanganan implikasi yang mungkin timbul dari penerapan aturan hukum tersebut. Dengan demikian, berbagai masalah kehidupan yang terus bermunculan dapat disentuh dengan pendekatan yang bersifat holistik dari upaya preventif, diagnosa sosal, hingga antisipasi terhadap "limbah" yang timbul sebagai implikasi pemberlakuan suatu aturan hukum. Pendekatan "struktural" seperti itu juga akan menghindarkan munculnya konsep-konsep hukum yang tidak konsisten dan substansinya kontradiktif satu sama lain.

\section{Metode Pengembangan}

Dalam diskursus hukum Islam harus selalu dibuka peluang munculnya konsep pemikiran baru, baik dalam substansi aturan hukum, metode istinbâth maupun strategi penerapannya.

Pengembangan metode istinbatth tidak boleh hanya didasarkan pada makna literal dan hasil deduksi atas teks-teks syari'ah, melainkan dengan menggabungkan makna literal, pesan sosiomoral, dan pertimbangan situasi sosial masyarakat.

Dalam konteks ini perlu rekonstruksi pola pengembangan konsep hukum dengan bertolak dari visi sosio-moralnya dan bukan berangkat dari pendekatan parsial kasus demi kasus secara terpisah. Langkah ini dimaksudkan agar setiap konsep hukum 
memiliki visi dan landasan etika yang kuat sehingga ia memiliki kepekaan yang diperlukan untuk merespons berbagai perkembangan sosial yang ada serta lebih mudah diterima oleh rasionalitas masyarakat modern.

Al-Qur'an telah memberikan penjelasan tentang masyarakat dan karakteristik idealnya. Berdasarkan penjelasan itulah, seharusnya setiap konsep hukum dikembangkan dan diimplementasikan. Institusi-institusi yang sudah ada dan konsep yang dikembangkan para ulama pada abad pertengahan hendaknya tidak dianggap sebagai konsep yang final, melainkan perlu dikaji lagi secara kritis dan dikembangkan sesuai dengan tantangan historisnya.

Institusi tersebut harus dipandang sebagai instrumen untuk meraih tujuan dan cita-cita moral yang lebih jauh dan bukan tujuan itu sendiri. Oleh karena, itu instrumen tersebut harus diubah jika keberadaannya justru lebih banyak merugikan nilainilai fundamental yang diabadikan dalam al-Qur'an ${ }^{48}$ atau tidak lagi memiliki "daya dorong" (transformative drive) ke arah perbaikan kehidupan umat. Warisan intelektual ulama di masa lalu, dengan kelebihan dan keterbatasan mereka yang amat manusiawi, tidak dapat disejajarkan sepenuhnya dengan firman Allah swt, yang suci dan abadi. ${ }^{49}$

Untuk mendorong perkembangan konsep fiqh yang lebih memiliki spirit transformasi sosial, perlu dilakukan sejumlah langkah sebagai berikut.

Pertama, mengembangkan pemikiran tentang pesan etika dan visi sosial Islam, baik visi Islam secara keseluruhan maupun yang menyentuh bidang-bidang tertentu, misalnya dalam ritual, politik, ekonomi, dan sosial-budaya. Kajian awal mengenai aspek filsafat hukum (falsafah al-tasyrî) ini dimaksudkan untuk mengkonstruksi konsep cetak biru (blue print) karakteristik individu dan masyarakat yang dicita-citakan.

Dalam memahami "isi“" teks al-Qur'an dan sunnah Nabi, pertanyaan pokok yang dikaji tidak berhenti pada makna literal teks itu kata demi kata, melainkan pada arah "perubahan" yang diinginkan oleh teks itu secara keseluruhan. Untuk memahami

${ }^{48}$ Engineer, Islam . . , 55.

${ }^{49}$ Ibid., 25. 
hal tersebut, di samping mengumpulkan ayat-ayat al-Qur'an dan teks sunnah yang valid, harus dilakukan pula telaah lintas teks (intertexts analysis) dan analisis sosio-historis lahirnya teks-teks syari'ah tersebut. Setiap teks harus "dibaca" bersamaan dengan teks-teks lain yang mengandung kesamaan tema sentral dengan memperhatikan konteksnya masing-masing untuk menemukan arah pesan umum yang terkandung di dalamnya.

Melalui pengkajian yang cermat, akan diperoleh sejumlah kemungkinan konklusi, misalnya apakah sebuah teks syari'ah berisi pesan-pesan moral utama atau berisi opsi-opsi dalam strategi penerapan hukum syariah dalam kehidupan sosial, atau mungkin sebatas deskripsi atas situasi atau peristiwa yang terjadi di era pewahyuan ('ahd al-nu₹ûh). Mungkin juga suatu teks tidak mengandung pesan utama secara mandiri, melainkan berfungsi sebagai pengantar atau penegasan atas isi teks lain yang menyampaikan pesan utama. ${ }^{50}$

Kedua, melakukan riset dan kajian kritis atas kehidupan masyarakat dari perspektif visi sosio-moral Islam yang telah dikonstruksi tersebut. Langkah ini dilakukan untuk mengidentifikasi fakta-fakta kesenjangan antara realitas sosial (das sein) dengan apa yang dicita-citakan (das sollen), faktor-faktor yang melatarinya serta modal sosial (social capital) yang tersedia untuk menanganinya.

Kajian tersebut diperlukan guna mendapatkan data yang akurat tentang masalah yang tengah dihadapi umat dan alternatif langkah yang dapat dilakukan untuk menanganinya. Dalam hal ini keterlibatan para spesialis dan pakar diperlukan untuk melihat, menganalisis, dan memberikan penjelasan ilmiah. Dengan demikian, setiap masalah akan dapat dikaji secara luas dan mendalam berdasarkan fakta dan data yang aktual dan terpercaya.

Ketiga, memilih prioritas tema-tema dan isu-isu sosial yang paling strategis dan dapat diharapkan membawa pengaruh luas

50 Pola penyampaian pesan seperti ini banyak terdapat dalam al-Qur'an. Misalnya pada Qs. al-Tîn (95), isi pesan utama yang disampaikan adalah terdapat pada ayat ke-4 dan seterusnya, sedangkan ayat 1 - 3 lebih merupakan "pengantar" yang berfungsi untuk mempertegas isi pesan-pesan tersebut. 
di berbagai lini kehidupan. Tema tersebut ditangani dengan desain pendekatan yang komprehensif dari berbagai sisi sehingga pengaruh positifnya dapat diharapkan menyebar ke berbagai aspek lainnya. Langkah ini perlu dilakukan karena lingkup permasalahan kehidupan manusia amat luas dan berkembang terus-menerus sehingga tidak perlu ditangani semuanya lewat pendekatan legal formal satu demi satu hingga aspek teknis yang sekecil-kecilnya.

Demikian pula tidak semua masalah perlu dijawab satu per satu dengan hujjah dan logika hukumnya sendiri-sendiri karena banyak di antaranya yang sifatnya amat teknis, situasional, dan debatable. Perhatian yang terlalu besar terhadap hal-hal kecil yang sifatnya sangat teknis dan situasional justru akan melupakan agenda-agenda yang lebih besar dan strategis, berpotensi menimbulkan perdebatan yang kurang produktif serta berdampak pada perpecahan di antara para ulama dan warga masyarakat. Melalui kajian atas tema-tema strategis yang paling urgen tersebut, juga dapat diidentifikasi bagian-bagian dari aturan hukum syari'ah yang lebih cocok diterapkan lewat jalur politik (legal policy) melalui undang-undang negara, jalur pendidikan, khotbah Jumat, ceramah di TV, bulletin, rubrik kolom hukum di majalah, situs internet, atau lewat media komunikasi massa lainnya.

Keempat, merumuskan konsep aturan hukum sesuai dengan situasi dan kesiapan sosiologis masyarakat dengan tetap mengarahkan pandangan ke depan pada visi sosio-moralnya. Bentuk riil dari aturan hukum yang dipilih dapat mengambil contoh-contoh yang pernah dilaksanakan di masa lalu atau dengan mengembangkan konsep baru, yang lebih sesuai dengan kebutuhan.

Sejalan dengan perkembangan kehidupan, konsep aturan hukum perlu terus disempurnakan secara bertahap ke arah format yang lebih ideal. Dalam konteks inilah sejumlah kalangan intelektual menyatakan bahwa fiqh (sebagai konsep pemikiran hukum) berkembang dan berinteraksi dengan situasi dan kondisi masyarakat. ${ }^{51}$

${ }^{51}$ Ahmad Chatib, Hukum Islam dan Perubahan Masyarakat Jakarta: Intermasa, 1980), 357-71. Lihat juga Yusuf Qardhawi, Ijtihad Kontemporer Kode 
Kelima, melakukan langkah-langkah riil untuk menerapkan konsep hukum yang telah dipilih, baik melalui jalur legislasi perundang-undangan (lewat lobi-lobi politik), perbaikan kurikulum pendidikan, penyusunan kitab-kitab fiqh yang baru, pengembangan kurikulum pengajaran fiqh, perumusan kembali tema dakwah, penyelenggaraan seminar, kajian maupun eveneven budaya lainnya.

Termasuk dalam langkah ini adalah capacity building dan networking antarinstitusi sosial yang sudah ada (seperti lembaga pengelola masjid, madrasah, BAZIS, ormas Islam, dan partai politik), serta pembentukan institusi-institusi baru yang dirancang sebagai uji coba pada taraf pelaksanaan teknis, misalnya mendirikan lembaga-lembaga mikro dalam perbankan, pegadaian dan asuransi berbasis syariah. Setelah diuji coba dan desainnya disempurnakan, model tersebut dapat diterapkan dalam skala yang lebih luas demi meningkatkan kesejahteraan umat.

\section{Catatan Akhir}

Agar syari'ah Islam, (yang secara sosiologis antara lain terekspresikan dalam bentuk fiqh) memiliki peran yang semakin penting dalam kehidupan masyarakat, ia harus memiliki spirit transformasi sosial yang menjiwai visi, isi, strategi maupun langkah sosialisasinya dalam kehidupan masyarakat. Dengan visi transformatif yang kuat, fiqh akan menjadi alternatif yang kian menarik bagi masyarakat modern setelah sistem-sistem sekuler yang ada selama ini makin banyak menampakkan kegagalannya dalam membangun kesejahteraan sosial yang didasarkan pada nilai keadilan, kemanusiaan, dan spiritualitas. Fiqh juga akan terasa lebih sederhana namun komprehensif, argumentatif dan lebih mudah diterima oleh rasionalitas masyarakat modern.

Di samping itu image syari'ah Islam juga akan berubah dari kesan statis, konservatif, keras, dan cenderung pro status quo menjadi lebih dinamis, inovatif, dan berwawasan jauh ke depan. Pola pemahaman tersebut juga akan membantu menunjukkan

Etika dan Berbagai Penyimpangannya, ter. Abu Barzani (Surabaya: Risalah Gusti, 1995), 7-10. 
peta jalan bagi umat Islam dalam merumuskan, mengutamakan dan menerapkan ajaran Islam di semua aspek kehidupan dalam pentas sejarah.

\section{Daftar Pustaka}

Abdallah M. al-Husayn al-'Amiri, Dekonstruksi Sumber Hukum Islam, Pemikiran Hukum Najm ad-Din Thufi, ter. Abdul Basyir (Jakarta: Gaya Media Pratama, 2004).

Abd al-Wahhâb Khallâf, 'Ilm Ushûl al-Fiqh (Jakarta: Majlis al-

A'la al-Indunisi li al-Da'wah al-Islamiyyah, 1972).

Abû 'Abd al-Lâh Muhammad bin Ismấîl al- Bukhârî, Matn alBukhâri, (Jeddah, Singapura-Indonesia,:al-Haramain, tt.).

Ahmad Chatib, Hukum Islam dan Perubahan Masyarakat (Jakarta: Intermasa, 1980).

Amiur Nuruddin, Ijtihad Umar bin Khaththab Studi tentang Perubahan dalam Hukum Islam (Jakarta: Rajawali Press, 1991).

Asghar Ali Engineer, Islam dan Pembebasan, ter. Hairus Salim HS \& Imam Baehaqi (Yogyakarta: LKiS, 1993).

Fazlur Rahman, "Hukum dan Etika dalam Islam", dalam Jurnal Al-Hikmah (Bandung: Yayasan Muttahari, no.9/1993).

Ibn Rusyd, Bidâyâh al-Mujtahid wa Nihâyah al-Muqtashid, Juz I (Ttp: Dar Ihya al-Kutub al-'Arabiyyah, tt).

John L. Esposito, Islam Warna-warni Ragam Ekspresi Menuju Jalan Lurus (al-Shirath al-Mustaqim) (Jakarta: Paramadina, 2004).

Kazuo Shimogaki, Kiri antara Islam Modernisme dan Post-modernisme Telaah Kritis atas Pemikiran Hassan Hanafi (Yogyakarta: LKiS, 1993).

Miftahul Huda, "Keragaman Fiqh dan Spirit Pembebasan Kajian atas Pemikiran al-Sya'rani (1492-1565) tentang Ikbtilâf dalam al-Mizân al-Kubrẩ' dalam Jurnal Istinbâth (Mataram: Fakultas Syariah IAIN Mataram) nomor 2 vol 4 Juni 2007.

Muhammad Abû Zahrah, Ushûl al-Figh, (Bairut: Dâr al-Fikr, tt). Muhammad al-Khudlari Bik, Târîkh al-Tasyrî' al-Islâmî (Dar Ihyâ' al-Kutub al-'Arabiyyah Indunisia, 1981).

Muhammad Nashiruddin al- Albani,, Fatawa al-Madinah alMunawwarah Fatwa-fatwa Syekh Nashiruddin al-Albani, ter. 
Taqdir Muhammad Arsyad (Yogkajarta: Media Hidayah, 2004).

Sifat Shalat Nabi SAW, ter. Muhammad Thalib (Yogyakarta: Media Hidayah, 2000).

Muhammad Saied. al-Asymawi, "Fiqh Islam" dalam Islam Negara dan Hukum, ed. Heijer, dkk. (Jakarta: INIS, 1993).

Munawir Syadzali, Ijtihad Kemanusiaan (Jakarta: Paramadina, 1997).

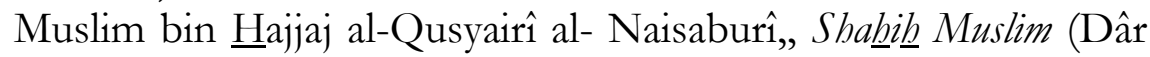
Ihyâ al-Kutub al-Arabiyyah Indunisiyyah, tt.).

Noel J., Coulson, Hukum Islam dalam Perspektif Sejarah, terj. Hamid Ahmad (Jakarta: P3M, 1987).

Sayyid Ahmad al- Hâsyimî, Mukehtar al-Ahâadits al-Nabawiyyah wa al-Hikam al-Mubammadiyyah (Semarang: Toha Putra, tt).

Yusuf Qaradhawi, Ijtihad Kontemporer Kode Etik dan Berbagai Penyimpangannya, ter. Abu Barzani (Surabaya: Risalah Gusti, 1995). 